\title{
«Мы должны вести твердый план»: к истории рассмотрения первого варианта Генерального плана реконструкции Москвы в июле 1934 года

\author{
Ю.Д.Старостенко, НИИТИАГ, Москва
}

В центре внимания статьи находится процесс трансформации ключевых установок Генерального плана реконструкции Москвы после первого его рассмотрения ЦК ВКП(б) в июле 1934 года. Изучение этих изменений стало возможным благодаря выявленной в фонде архитектора П.И. Гольденберга (РГАЭ) схеме основных радиальных и кольцевых магистралей Москвы, подготовленной в 1934 году Отделом планировки Моссовета. Эта схема, отпечатанная типографическим образом большим тиражом, является одним из немногих свидетельств того, что архитекторы - авторы проекта планировки - и московское руководство в лице Л.М. Кагановича рассчитывали на утверждение представленного ими проекта. В статье особое внимание уделяется анализу выявленной схемы и рассмотрению её отличий от схемы планировки 1935 года. На основании документов из фонда Л.М. Кагановича (РГАСПИ) также предпринимается попытка реконструировать процесс пересмотра тех ключевых установок, которые лежали в основе схемы планировки в 1934 году, и воссоздать те принципы, которыми руководствовались архитекторы при внесении изменений в схему планировки уже в 1935 году. В частности, рассматриваются события, последовавшие за обсуждением Генерального плана реконструкции Москвы ЦК ВКП(б) в июле 1934 года и приведшие к появлению через год постановления СНК СССР и ЦК ВКП(б) «0 Генеральном плане реконструкции г. Москвы», а также те изменения, которые после совещания 1934 года были внесены в схему планировки Москвы. Эти материалы в совокупности позволяют с качественно иных позиций увидеть события июля 1934 года, пересмотреть их роль в истории создания Генерального плана реконструкции Москвы 1935 года и определить степень их влияния на дальнейшее развитие города ${ }^{1}$.

Ключевые слова: Генеральный план, проект планировки, реконструкция Москвы, советское градостроительство, В.Н. Семёнов, С.Е. Чернышёв, Л.М. Каганович.

"We Must Keep a Firm Plan": on the History of Consideration of the First Version of the General Plan for the Reconstruction of Moscow in July 1934

Yu.D. Starostenko, NIITIAG, Moscow

The article focuses on the key elements of the General plan for the reconstruction of Moscow transformation process after its first consideration by the Central Committee of the Communist Party of the Soviet Union in July 1934. The study of these changes was made possible thanks to the scheme of the main radial and ring highways of Moscow prepared in 1934 by the Planning Department of the Moscow Soviet, which was revealed in the Fund of architect P. I. Goldenberg (Russian state archive of economics). This scheme, printed in a large number of copies, is one of the few shreds of evidence that the architects - the authors of the planning project - and the Moscowleadership in the person of L.M. Kaganovich in July 1934 looked forward to the approval of the presented project. Particular attention devoted to the analysis of the revealed scheme and consideration of its differences from the planning project 1935. On the basis of documents from the L.M. Kaganovich Fund (The Russian State Archive of Socio-Political History, RGASPI) an attempt to reconstruct the process of revising the key settings, that formed the basis of the layout of the planning scheme in 1934 and try recreate principles which guided the architects in the changes to the General plan already in 1935 is also undertaken. In particular, we consider the events that followed the discussion of the General plan for the reconstruction of Moscow in Central Committee of the Communist Party of the Soviet Union in July 1934 andled to the appearance in a year the decision of the party and government "On the General plan for the reconstruction of Moscow", as well as those changes that after the meeting in 1934 were made to the Moscow planning schematics. These materials together allow us to see the events of July 1934 from a qualitatively different perspective, to review their role in the history of the General plan for the reconstruction of Moscow in 1935 and to determine the extent of their impact on the further development of the city.

Keywords: General plan, planning project, reconstruction of Moscow, Soviet urban planning, V.N. Semenov, S.E. Chernyshev, L.M. Kaganovich.

Тот факт, что Генеральный план реконструкции Москвы, утверждённый в 1935 году, впервые был представлен на рассмотрение ЦК ВКП(б) годом ранее, в июле 1934 года, сегодня практически забыт. Между тем, в 1930-е годы он был достаточно хорошо известен. 0 нём упоминали в своих статьях архитекторы, он был зафиксирован в речи Л.И. Кагановича «0 строительстве метрополитена и плане города Москвы» на пленуме Моссовета с участием ударников Метростроя, фабрик и заводов, которая прозвучала 16 июля 1934 года

Исследование выполнено за счёт средств Государственной программы Российской Федерации «Развитие науки и технологий» на 2013-2020 годы в рамках Плана фундаментальных научных исследований Минстроя России и РАACH, тема 1.2.3. 
[через два дня после совещания в ЦК ВКП(б)] и позднее была опубликована не только в газетах, но и в виде отдельной брошюры [1]. Более того, этот факт можно найти в книге «Генеральный план реконструкции Москвы» (1936) [2, с. 45], которая до настоящего времени остается одним из ключевых источников для тех, кто занимается исследованиями по истории преобразования Москвы в 1930-е годы. Возможно, точно выверенный текст книги, в котором этот сюжет был сведён к краткому упоминанию и представлен как мало значимый в истории создания Генерального плана 1935 года² $^{2}$ и определил то обстоятельство, что рассмотрение Генерального плана за год до его утверждения никогда не становилось предметом специального исследования. Хотя, безусловно, упоминания о нём встречаются в публикациях, посвящённых истории преобразования Москвы 1930-х годов [4, с. 111].

Ввиду отсутствия каких-либо публикаций в профессиональной архитектурной печати за 1934 год, тремя источниками, по которым можно было судить о том варианте Генерального плана, который был представлен на первое рассмотрение ЦК ВКП(б), были: обобщённая схема основных магистралей Москвы, публиковавшаяся с докладом Л.М. Кагановича (рис. 1), сам доклад и статья Д.М. Арановича в октябрьском выпуске журнала «Новый мир» за 1934 год [5]. Речь Л.М. Кагановича содержала лишь общие положения проекта планировки. Схема магистралей была крайне приблизительной и позволяла однозначно утверждать только тот факт, что в 1934 году создания нового юго-западного района Москвы еще не предполагалось. В статье, которая была

2 Подробнее об истории появления книги см.: [3].

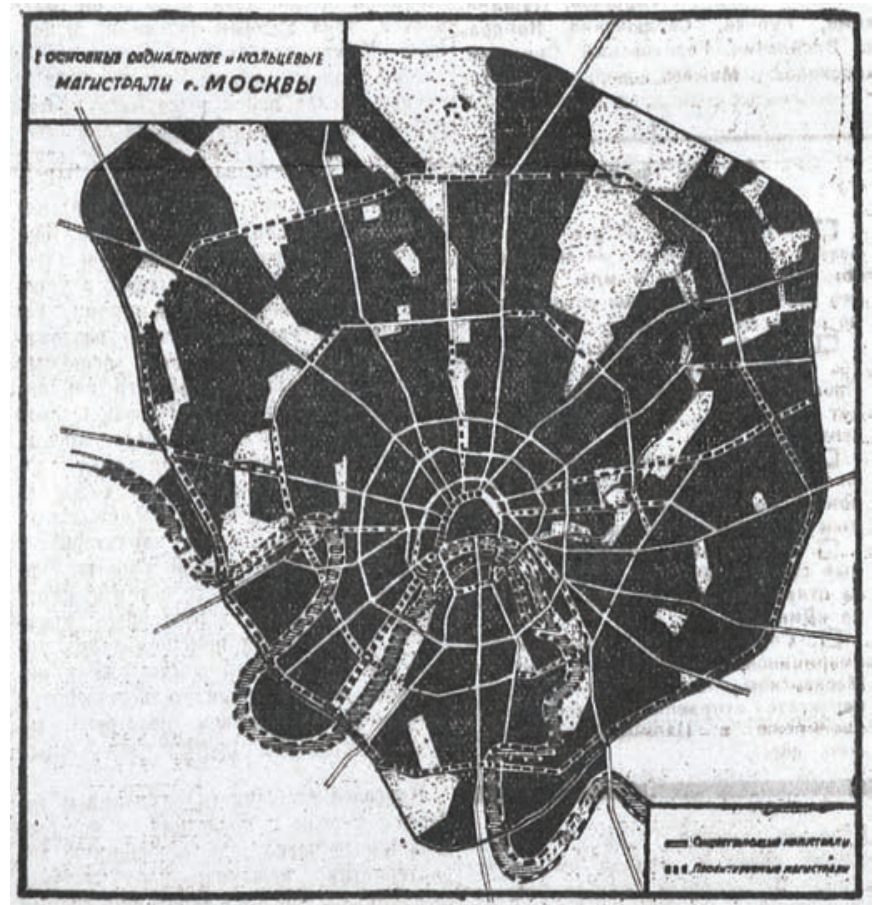

Рис. 1. Схема основных радиальных и кольщевых магистралей 2. Москвы [1, с. 24] опубликована в «Новом мире», затрагивалось очень много разных аспектов реконструкции города - от истории разработки проекта планировки до уже шедшей реконструкции набережных, а потому описанию проекта планировки отводился относительно небольшой объём текста, написанный к тому же с расчётом на широкий круг читателей.

Однако эта статья ценна прежде всего тем, что даёт представление о том, как воспринималось рассмотрение Генерального плана в июле 1934 года архитекторами. Д. Аранович в тексте прямо указывал, что «генеральный проект социалистической реконструкции Москвы был подвергнут обсуждению на специальном совещании ЦК партии при участии тов. Сталина, тов. Кагановича и крупнейших архитектурных сил Москвы» и что «все основные положения последнего генерального проекта планировки Москвы были на этом совещании одобрены» [5, с. 137]. И в дальнейшем при описании проекта планировки говорил о нём, как о «принятом и находящемся в действии проекте», иными словами, как об утверждённом. Правда, словам Д. Арановича можно противопоставить молчание профессиональной прессы, которая не упоминает о рассмотрении проекта летом 1934 года (если на считать публикации речи Л.М. Кагановича в журнале «Строительство Москвы» даже без схемы основных магистралей [6]). Вероятно, в случае безоговорочного одобрения этой схемы ситуация была бы иной. Можно предположить, что статья Д. Арановича, как и многие тексты тех лет, приуроченные к важным событиям, готовилась заранее исходя из того, что проект планировки будет утверждён, и была опубликована без существенных правок в силу неизвестных обстоятельств.

Ещё одним косвенным свидетельством того, что решение совещания в июле 1934 года было для московских властей и архитекторов неприятной неожиданностью, является схема «0сновных радиальных и кольцевых магистралей г. Москвы», датированная 1934 годом и выявленная в фонде архитектора П.И. Гольденберга (РГАЭ) ${ }^{3}$ (рис. 2). Примечательным эту находку делает то обстоятельство, что это не графический лист, а схема, изданная типографским способом журналом «Строительство Москвы» в количестве 15 тысяч экземпляров. Так и не ставшая приложением к очередному выпуску журнала, сообщавшему об утверждении Генерального плана в июле 1934 года, эта схема по своему графическому решению близка той, которая с аналогичным названием была издана через два года как приложение к книге «Генеральный план реконструкции г. Москвы» (рис. 3). И именно поэтому она даёт уникальную возможность детально изучить версию проекта планировки столицы середины 1934 года

\footnotetext{
${ }^{3}$ Основные радиальные и кольцевые магистрали г. Москвы (схема). Масштаб 1:40 000 / Отдел планировки Моссовета, 1934 // РГАЭ. Ф. 185. 0п. 1. Д. 210. Л. 128.

4 Тот факт, что это издание схемы 1934 года, выявленной в фонде П.И. Гольденберга, было приурочено к первому рассмотрению Генерального плана, не вызывает сомнения. Иного повода для публикации в 1934 году такой схемы выявить не удалось.
} 


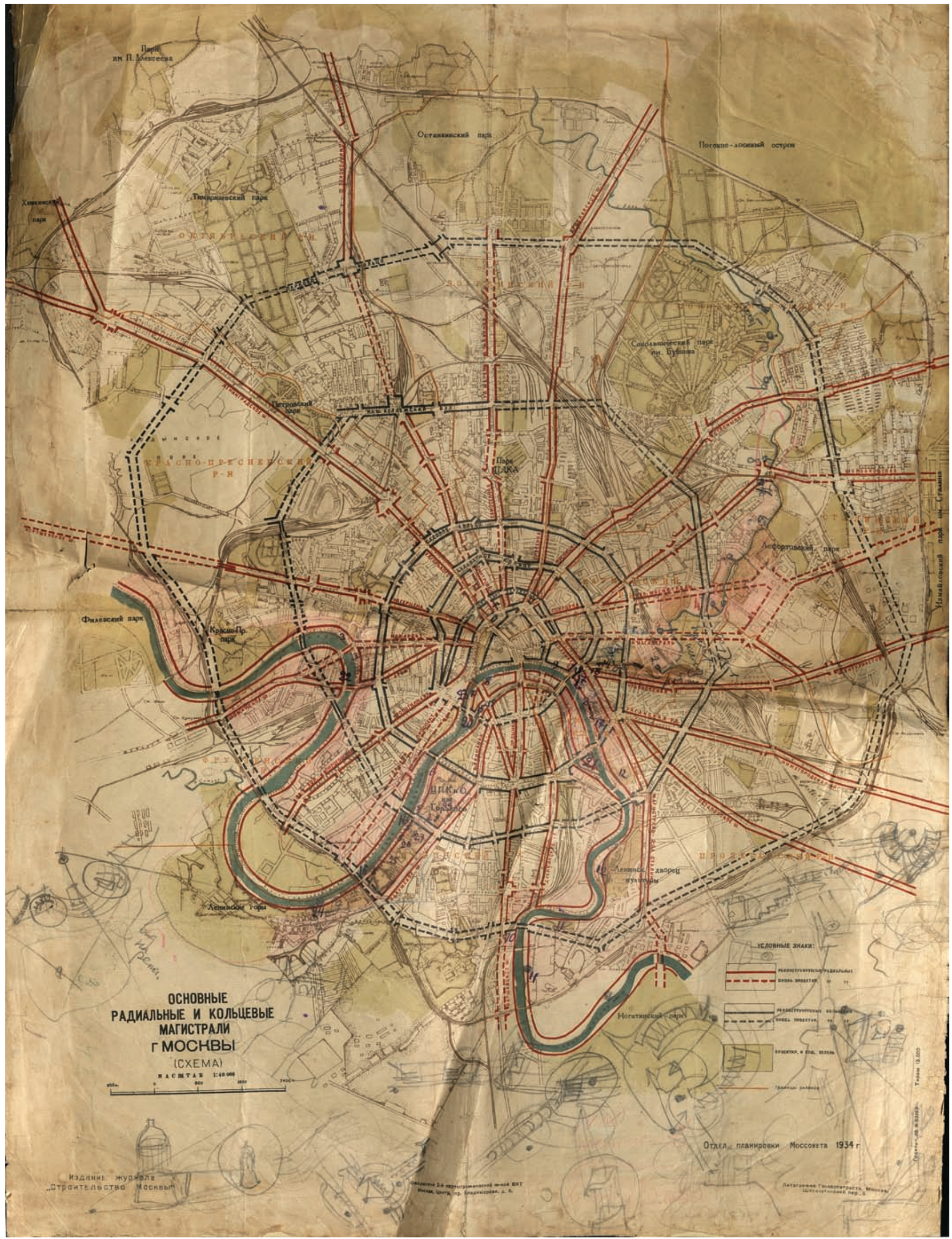

Рис. 2. «Основные радиальные и кольцевые магистрали г. Москвы» (схема). Отдел планировки Моссовета. 1934 год5 


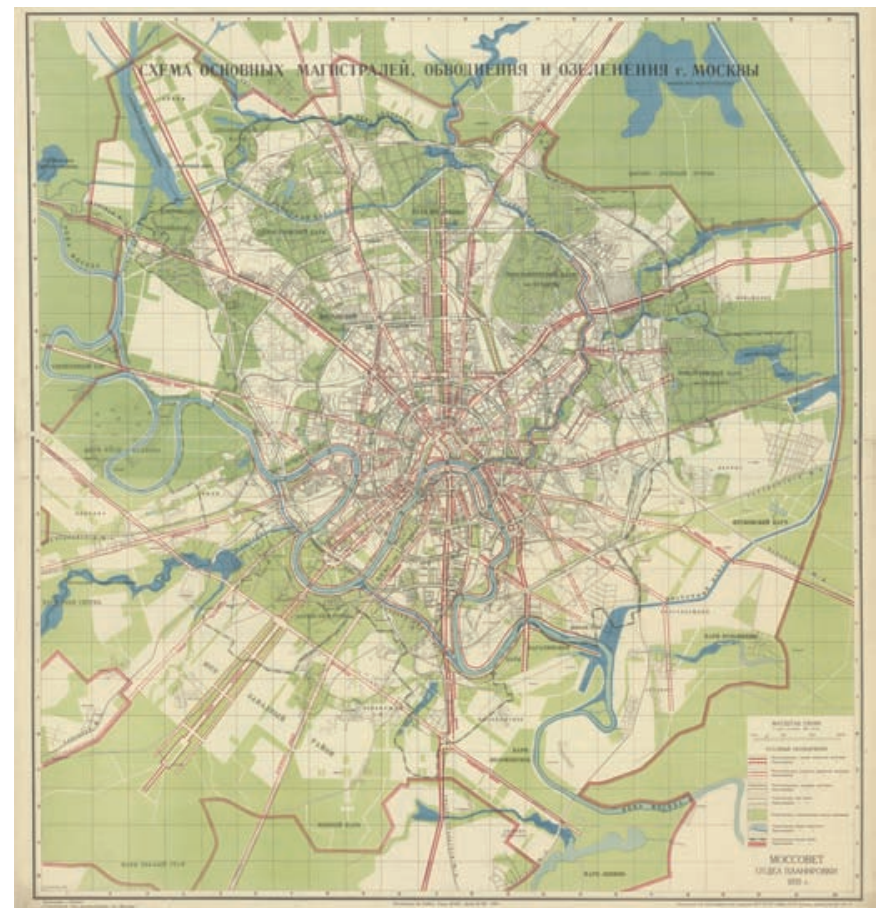

Pис. 3. Схема основных магистралей, обводнения и озеленения г. Москвы. Моссовет, Отдел планировка. 1935 год [2, приложение]

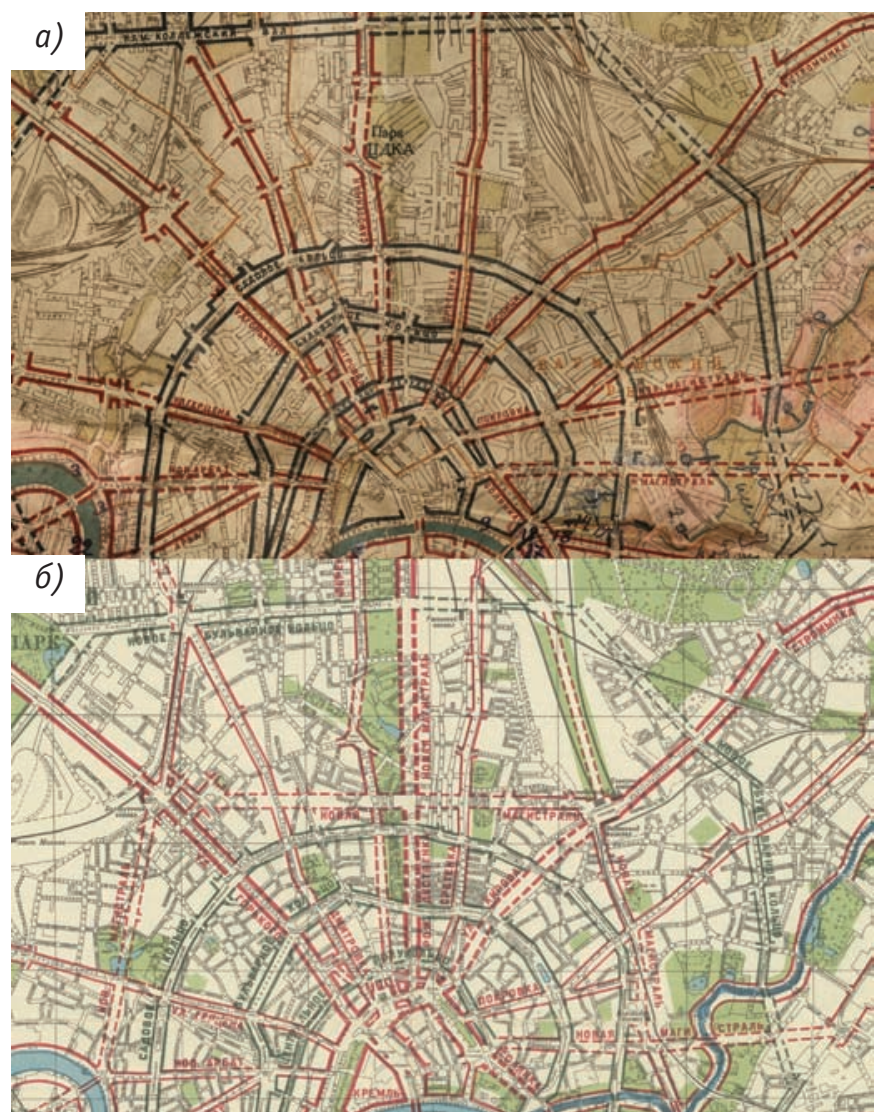

Puc. 4. Сопоставление схем планировки 1934-го (а) года и 1935-го (б) годов. На схеме 1935 года. показаны три «обходные» магистрали, которых нет на схеме 1934 года, а на схеме 1934-го - новая магистраль от Покровки в сторону Лефортово, которой нет на схеме 1935 года
Помимо очевидного отсутствия юго-западного района, а, следовательно, и всей сети намечавшихся на новой территории улиц, на схеме 1934 года также нет некоторых новых магистралей, которые планировалось прокладывать через уже существовавшую застройку. Прежде всего на схеме отсутствует так называемая магистраль «север-юг», идущая от Останкинского парка через Рождественку и центр на Ордынку и далее - на спрямлённое Серпуховское шоссе. Нет «обходных» магистралей, которые в 1935 году намечались: первая - от площади, образуемой Новым Арбатом у Москвы-реки, через площадь Белорусского вокзала к Савёловскому вокзалу, вторая - от площади Белорусского вокзала к Комсомольской

${ }^{5}$ 0сновные радиальные и кольцевые магистрали г. Москвы (схема). Масштаб 1:40 000 / Отдел планировки Моссовета, 1934 // РГАЭ. Ф. 185. Оп. 1. Д. 210. л. 128.

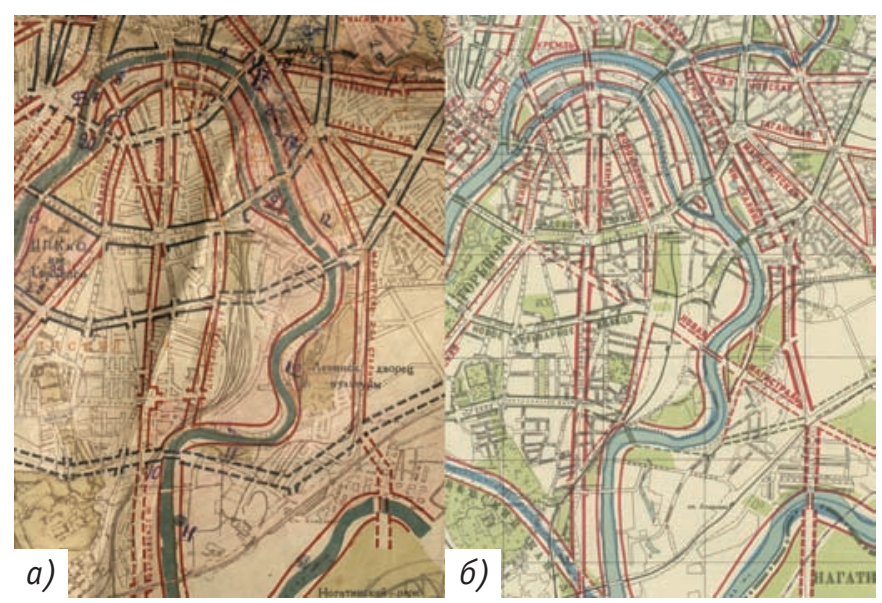

Puc. 5. Сопоставление схем планировки 1934-го (а) и 1935-го (б) годов. На схеме 1935 года показана новая магистраль от Октябрьской площади к Южному порту, которой нет на схеме 1934 года, а также изменённая трассировка Паркового кольца и Андреевский канал.

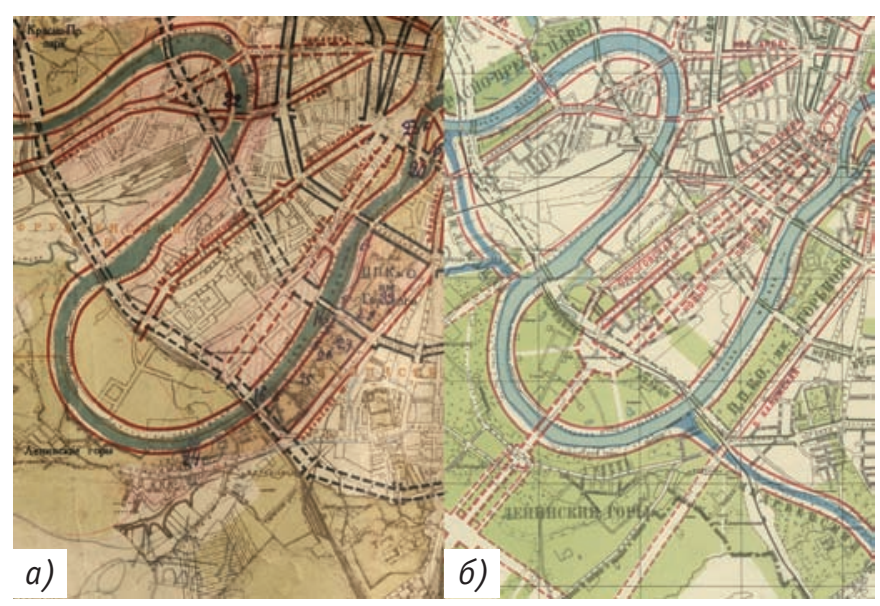

Рис. 6. Сопоставление схем планировки 1934-го (а) и 1935-го (б) годов. Варианты планировки Аллеи Ильича от Дворца Советов к Ленинским (Воробьёвым) горам 
площади, третья - от пересечения с парковым кольцом через Комсомольскую площадь мимо Курского вокзала ${ }^{6}$ к Абельмановской заставе и далее - к Южному порту (рис. 4), четвертая - от Октябрьской площади к Южному порту (рис. 5).

Иначе в проекте 1934 года была спроектирована Аллея Ильича, ещё не получившая логического завершения в виде центральной магистрали нового юго-западного района (рис. 6). Она трактовалась, как широкая улица от площади Дворца Советов практически параллельно Москве-реке до пересечения с вновь прокладываемым Парковым кольцом. Трасса самого Паркового кольца, как и других новых кольцевых магистралей - Нового Бульварного кольца, продолжения Бульварного кольца в Замоскворечье, Центрального полукольца, - практически совпадала в обоих вариантах проекта планировки, если не считать промежутка Паркового кольца от пересечения с Большой Калужской улицей до новой площади севернее Кожухово. В проекте 1934 года на этом участке трасса кольца проектировалась заметно южнее, но в то же время в проекте планировки 1934 года не были показаны ни Андреевский, ни Дорогомиловский каналы, русло которых намечалось в 1935 году практически параллельно Парковому кольцу. Также в проекте 1934 года не были отражены предложения по регулированию русла реки Яузы и какие-либо иные элементы проекта обводнения Москвы.

Единственной новой магистралью, которая предполагалась в проекте планировки 1934 года, но не была сохранена в проекте 1935-го, была улица, намечавшаяся как продолжение Покровки в сторону Лефортово (см. рис. 4).

В целом схему планировки Москвы 1934 года при сопоставлении со схемой 1935-го можно охарактеризовать как достаточно осторожную. Она предполагала заметно меньший масштаб сносов благодаря отсутствию «обходных» магистралей и во многом следовала тем установкам, которые были озвучены в 1932-1933 годы первым секретарём МК и МГК ВКП(б) Л.М. Кагановичем как главным представителем заказчика реконструкции столицы в лице Политбюро ЦК ВКП(б)». Так, раскритиковав предложения по перепланировке Москвы, подготовленные к середине 1932 года семью бригадами советских и иностранных архитекторов, за отказ от ограничения роста территории Москвы, за попытки коренного изменения планировочной структуры города путём прокладки новых магистралей и т.п., Л.М. Каганович тем самым вполне определённо дал понять, какие решения являются для заказчика неприемлемыми. То, что архитекторы разрабатывали свои планировочные решения, сознавая темпы роста города и исходя из задачи размещения населения столицы в благоприятных условиях, тогда Л.М. Кагановичем было проигнорировано. С его точки зрения речь могла идти только об «исправлении» планировочной структуры Москвы путём спрямления и расширения улиц без применения таких радикальных мер, как создание принципиально новой планировочной структуры города. Расширению территории города он противопоставлял увеличение этажности и изыскание земель внутри существующих границ Москвы.

В этой связи можно вспомнить, как в 1932 году В.Н. Семёнов, руководивший разработкой проекта планировки Москвы в 1930-1934 годы (то есть как раз в тот период, когда создавалась схема 1934 года), предлагал ради размещения нового жилищного строительства прекратить экстенсивную застройку Москвы, освободить территорию города от части вспомогательных железнодорожных путей и сооружений, а также вывести за пределы столицы учреждения, напрямую не связанные с городом [7, с. 2]. Невозможность реализации этого подхода на практике со временем становилась всё очевиднее по мере разработки проекта планировки. Наркомат путей сообщения не стремился выводить товарные и сортировочные станции за пределы Москвы, не стремился сокращать полосы отвода вдоль линий железных дорог, проходящих по территории города. Учреждения и ведомства, обосновавшиеся в столице, всеми силами старались не попасть в поле зрения комиссий по разгрузке Москвы. В результате, принципы, лежавшие в 1934 году в основе разработки проекта планировки, уже не отвечали реальной ситуации, а архитекторы, скованные той критикой, которая обрушилась на проекты планировки Москвы в 1932 году, не могли взять на себя инициативу по пересмотру этих принципов.

Итогом масштабного рассмотрения проекта в июле 1934 года стало весьма краткое решение Политбюро ЦК ВКП(б), зафиксированное в одном из его протоколов: «а) Принять в основном предложенную Московским Комитетом ВКП(б) и Моссоветом намётку (курсив мой - Ю.С.) планировки города Москвы. б) Поручить Московскому Комитету ВКП(б) и Моссовету внести в правительство на основе обмена мнений проект конкретных предложений. Срок работы - один месяц» ${ }^{7}$. Такое решение, скорее всего, было свидетельством недовольства работой, которая была представлена московскими властями и архитекторами. Косвенно это подтверждается очень большим числом замечаний и пожеланий к представленному проекту со стороны И.В. Сталина, которые были упомянуты Л.М. Кагановичем в его речи на пленуме Моссовета 16 июля 1934 года и сохранились даже в сильно откорректированном опубликованном варианте речи. В оригинальной стенограмме, сохранившейся в архиве Л.М. Кагановича (РГАСПИ), таких замечаний заметно больше. Более того, в ней приводятся слова Л.М. Кагановича о том, что он передал «здесь только несколько основных установок, которые мы получили» ${ }^{8}$. Эта стенограмма также позволяет понять одну из ключевых проблем реконструкции столицы: «Мы должны вести твёрдый план», «...мы должны решительно

\footnotetext{
${ }^{6}$ По трассе Курско-Октябрьского железнодорожного диаметра, который в 1935 году планировалось переместить в туннель.

7 Решение Политбюро от 14.VII.34 г. «18/178. 0 планировании г. Москвы» // РГАСПИ. Ф. 17. 0п. 3. Д. 948. Л. 6.

${ }^{8}$ Стенограмма речи Кагановича Л.М. на пленуме Моссовета сучастием ударников Метростроя, фабрик и заводов Москвы о ходе строительства метрополитена. Неправленый экз. (16.07.1934 г.) // РГАСПИ. Ф. 81. 0п. 3. Д. 204. Л. 125.
} 
бороться с той стихийной застройкой, которая идёт в Москве, когда строит каждый дом там, где ему захочется» ${ }^{9}$. Иными словами, от архитекторов и московских властей заказчик ждал не «намётку», а реально действовавший документ. В то же время опубликованный вариант речи, в котором посвящённая плану Москвы часть была заметна дополнена рассуждениями о путях расширения территории города «на 50 проц. от существующей территории» [1, с. 22] и описанием схемы планировки, свидетельствует о том, что эти вопросы тоже не остались на совещании без внимания. И, вероятно, уже на самом заседании начался процесс пересмотра ключевых установок, лежащих в основе проекта планировки. Первым результатом этого пересмотра, зафиксированным в опубликованной версии речи Л.М. Кагановича, и стало изменение позиции относительно расширения территории города ради обеспечения жилищного строительства. Неприемлемое в 1932 году, в 1934-ом оно стало рассматриваться как единственно возможный путь решения одной из самых насущных проблем города.

К сожалению, свидетельств самих архитекторов о том, как происходило это столь важное для них совещание, практически не сохранилось. В конце 1960-х годов, когда ещё были живы непосредственные участники событий, архитектор П.И. Гольденберг, с 1930-х занимавшийся исследованием градостроительной истории Москвы, попытался собрать воспоминания у своих старших коллег. Однако полученные им от А.А. Карпова ${ }^{10}$, П.П. Шевалье ${ }^{11}$ и В.И. Долганова ${ }^{12}$ сведения были крайне обрывочны и, как всякие воспоминания, довольно неточны. У свидетелей не было единого мнения даже относительно имён докладчиков, представлявших проект планировки, но, скорее всего, ими были М.В. Крюков и В.Н. Семёнов. Архитекторы помнили саму атмосферу совещания, проходившего в Кремле, большой кабинет, где собралось всё руководство страны, но ничего не могли сказать о причинах, которые привели к переработке схемы планировки.

Трансформацию схемы планировки Москвы образца 1934 года в ту схему, которая в итоге была утверждена вместе с постановлением СНК СССР и ЦК ВКП(б) «0 Генеральном плане реконструкции г. Москвы» 10 июля 1935 года, позволяют проследить документы из фонда Л.М. Кагановича. Работа с этими документами, результаты которой частично публиковались ранее $[8]^{13}$, позволяет заключить, что вплоть до февраля 1935 года подготовка текста постановления была едва ли не важнее работы над схемой планировки Москвы. Вероятно, это было связано с необходимостью пересмотра прежних установок, на основании которых архитекторы могли бы выполнить свою часть работы, а возможно, и с тем обстоятельством, что первые варианты текста постановления были подготовлены архитекторами, и вопросы развития смежных с архитектурой отраслей хозяйства Москвы, как и вопросы связи архитектурной реконструкции с другими реализуемыми в столице проектами, в них практически не рассматривались. Подготовка дополнительных разделов постановления требовала привлечения специалистов и времени. Не менее важной задачей была подготовка документа, который бы обеспечил застройку города по «твёрдому плану», как того требовал И.В. Сталин. И в связи с этим необходимо упомянуть весьма солидный по объёму проект постановления ЦК ВКП(б) и СНК СССР «0б осуществлении генерального проекта планировки г. Москвы», разработанный под руководством А.Я Вышинского к февралю 1935 года и также выявленный в фонде Л.М. Кагановича ${ }^{14}$.

Коренная переработка схемы планировки Москвы началась 20 февраля 1935 года, когда Л.М. Кагановичем на совещании в Отделе планировки Моссовета впервые была озвучена идея о расширении Москвы на юго-запад [8, с. 242]. На трёх заседаниях Арплана - Комиссии МГК ВКП(б) и Моссовета по вопросам архитектуры и планировки Москвы, - состоявшихся 21, 27 и 28 февраля также под руководством Л.М. Кагановича, были определены и все другие корректировки, которые архитекторам необходимо было внести в схему 1934 года. Л.М. Каганович уже не настаивал на сохранении радиально-кольцевой планировочной структуры Москвы, «которая не является идеальной, которая не является для нас образцом» ${ }^{15}$. Более того, он видел много недостатков в «этом воронкообразном построении города» и призывал архитекторов «произвести коренную реконструкцию, сделать нечто смелое, нечто острое» ${ }^{16}$. В противовес своим собственным словам годичной давности о возможности «получить стройную радиально-кольцевую систему в 16-17 ровных радиальных улиц и 6 колец» [1, с. 24-25], 21 февраля 1935 года он говорил: «Вместо того, чтобы рассчитывать на 20 магистралей, давайте лучше сосредоточимся на 4-5. Если мы за 20 лет сумеем построить 4 хороших магистрали - это лучше, чем разменяться на 20 улиц» ${ }^{17}$. Исходя из этого, он предлагал

\footnotetext{
${ }^{9}$ Там же. Л. 122-123.

${ }_{10}$ [Письма А.А. Карпова П.И. Гольденбергу. 1969 г.] // РГАЭ. Ф. 109. 0п. 1. Д. 156. Л. 1, 2-2 об., 5 об., 7-7а., 8 об., 9 об., 11-11 об.

${ }^{11}$ [Воспоминания П.П. Шевалье о совещании Политбюро с участием 50 архитекторов-градостроителей. Москва, Кремль. 14 июля 1934 г., записанные П.И. Гольденбергом] // РГАЭ. Ф. 109. 0п. 1. Д. 109. Л. 277-278 об.

12 [Запись телефонного разговора П.И. Гольденберга с В.И. Долгановым. 1969 г.] // РГАЭ. Ф. 109. 0п. 1. Д. 156. Л. 3.

${ }^{13}$ На момент подготовки публикации с анализом текста постановления СНК СССР и ЦК ВКП(б) «0 Генеральном плане реконструкции г. Москвы», схема, рассматриваемая в настоящей статье, ещё не была найдена, а потому в фокусе внимания находились многочисленные варианты текста постановления «0 Генеральном плане реконструкции г. Москвы».

${ }^{14}$ Проект постановлений ЦК ВКП(б) и СНК СССР «Об осуществлении генерального проекта планировки г. Москвы», представленный в ЦК ВКП(б) А. Вышинским. 10.02.1935 г. // РГАСПИ. Ф. 81. 0п. 3. Д. 83. Л. 1-25.

${ }^{15}$ Стенограмма заседания комиссии Арплана Москвы. 21.02.1935 г. // РГАСПИ. Ф. 81. Оп. 3. Д. 185. Л. 127.

${ }^{16}$ Там же. Л. 128.

${ }^{17}$ Там же. Л. 130.
} 
наметить несколько сквозных диаметров через весь город, в том числе, опираясь на идею И.В. Жолтовского о соединении Петровки или Неглинки с Ордынкой, предлагал диаметр от Останкино до Варшавского шоссе (см. рис. 4). Он также говорил о существующей возможности соединить Комсомольскую площадь с площадью Белорусского вокзала и Сокольники с Пролетарским районом ${ }^{18}$. В результате участниками заседания были приняты следующие «соображения» Л.М. Кагановича: «...некоторые существующие радиальные магистрали сделать сплошными, не застопоривающимися в центре; сделать ряд новых улиц, наложить сетку на существующую радиальную систему; повернуть строительство на юго-западную территорию вдоль Москва-реки...» ${ }^{19}$. Таким образом, опираясь именно на эти установки, архитекторы под руководством С.Е. Чернышёва, который после рассмотрения проекта в июле 1934 года сменил В.Н. Семёнова на должности главного архитектора Отдела планировки, приступили к составлению той схемы планировки Москвы, которая была утверждена вместе с постановлением «0 Генеральном плане реконструкции г. Москвы».

Первые предложения архитекторов по конкретной трассировке магистралей рассматривались уже на следующем заседании Арплана 27 февраля. Слушая их, Л.М. Каганович настаивал на продлении диаметра, проходящего мимо Дворца Советов через Лужники (то есть Аллеи Ильича), на Воробьёвы горы и говорил, что «не будет Воробьёвых гор, разделяющих город на две части» ${ }^{20}$ (см. рис. 6). И хотя в центре внимания на этом заседании была планировка нового юго-западного района, на нём особо обсуждались варианты трассировки новой магистрали, связывающей вокзалы, и новая магистраль от Октябрьской площади к Южному порту, которая должна была обеспечивать связь Пролетарского района с Киевским вокзалом и Смоленской площадью (см. рис. 5). Примечательным на этом заседании было замечание Л.М. Кагановича о том, «что мы можем идти на создание магистрали, всё-таки имея в основе какую-то улицу», прозвучавшее в ответ на предложение архитекторов проложить магистраль из Замоскворечья мимо Дворца Советов на Красную Пресню21. При этом одним из главных критериев при обсуждении вариантов трассировок были объёмы сносимых квадратных метров жилой площади.

Промежуточный итог столь масштабному обсуждению был подведён на следующий день 28 февраля, когда Л.М. Каганович ещё раз обобщил все изменения, касающиеся проекта планировки. И хотя он утверждал, что «то, что мы приняли год тому назад, остаётся в целом в силе», что «мы сейчас берём за основу существующий старый город, соединив его с новой частью города», и что «в этом духе надо формулировать, исходя из тех документов, которые у нас имеются и внеся те коррективы, которые вытекают из новых наших поисков» 22 , реальные изменения, вносимые в схему планировки Москвы, имели решающее значение для последующего развития города.

Аналогичных материалов о разработке проекта планировки Москвы в период от конца февраля до 10 июля 1935 года, когда представленная архитекторами схема была утверждена, выявить на данный момент не удалось. Поэтому установить, почему некоторые из упоминавшихся на заседаниях Арплана новых магистралей так и не вошли в итоговую схему и когда в неё были включены некоторые магистрали, не обсуждавшиеся на этих заседаниях, не представляется возможным. Однако ценность трёх сохранившихся протоколов заседаний Арплана заключается прежде всего в том, что они позволяют зафиксировать тот момент, когда кардинальный пересмотр ключевых установок, лежавших в основе проекта планировки, нашёл воплощение в виде конкретных планировочных решений.

Суммируя все вышеизложенное, можно утверждать, что первое рассмотрение Генерального плана в июле 1934 года на самом деле не было формальным и оказало колоссальное влияние и на постановление СНК СССР и ЦК ВКП(б) «0 Генеральном плане реконструкции г. Москвы», и на приложенную к нему схему планировки столицы. Найденная и представленная в статье схема основных радиальных и кольцевых магистралей Москвы, изданная в 1934 году типографским способом довольно большим тиражом, наводит на мысль, что и московские власти, и архитекторы не были готовы к тому, что рассмотрение проекта планировки Москвы в июле 1934 года станет лишь ещё одним промежуточным этапом на пути к итоговому документу. Вероятно, это рассмотрение также стало основанием для ухода с должности главного архитектора Отдела проектирования В.Н. Семёнова и назначения на эту должность С.Е. Чернышёва, под руководством которого и проходила переработка проекта планировки.

Схема планировки Москвы за год, прошедший после первого рассмотрения в июле 1934 года, была коренным образом переработана. Именно в этот период были окончательно определены принципы, лежавшие в её основе, принято решение о расширении Москвы на юго-запад, сформулированы идеи трёх основных диаметров и «обходных» магистралей, которые и были воплощены в утверждённой в 1935 году схеме и стали неотъемлемой частью Генерального плана реконструкции Москвы.

Ещё одним практически забытым итогом обсуждения проекта планировки в июле 1934 года, на котором прозвучал призыв строить по «твёрдому плану», стала разработка документа, регламентирующего осуществление Генерального плана рекон-

\footnotetext{
${ }^{18}$ Там же.

${ }^{19}$ Там же. Л. 138.

${ }_{20}^{20}$ Стенограмма заседания архитектурно-планировочной комиссии. 27.02.1935 г. // РГАСпИ. Ф. 81. Оп. 3. Д. 186. Л. 7.

${ }^{21}$ Там же. л. 20.

${ }_{22}$ Стенограмма заседания комиссии Арплана (председатель Каганович Л.М.) по вопросам перепланировки Москвы. 28.02.1935 г. // РГАСПИ. Ф. 81. 0п. 3. Д. 186. л. 54.
} 
струкции Москвы. Упоминавшийся в тексте статьи обширный документ, представленный А.Я. Вышинским в феврале 1935 года, был переработан, и 1 октября 1935 г. постановлением СНК СССР были утверждены «Правила о порядке застройки города Москвы», которые должны были обеспечить реализацию всех мероприятий, намеченных постановлении СНК СССР и ЦК ВКП(б) «О Генеральном плане реконструкции г. Москвы».

\section{Лuтература}

1. Каганович, Л.М. 0 строительстве метрополитена и плане города Москвы : речь тов. Л. М. Кагановича на пленуме Моссовета с участием ударников Метростроя, фабрик и заводов Москвы 16 июля 1934 г. - М. : Издание газеты «Ударник Метростроя», 1934.

2. Генеральный план реконструкции города Москвы. Постановления и материалы. - М. : Московский рабочий, 1936.

3. Старостенко, Ю.Д. Книга «Генеральный план реконструкции города Москвы» 1936 года: история создания и ее роль в формировании представлений о реконструкции Москвы первой половины 1930-х годов // Архитектурное наследство. Выпуск 69 / главный редактор, составитель И. А. Бондаренко; филиал ФГБУ «ЦНИИП Минстроя России» Научно-исследовательский институт теории и истории архитектуры и градостроительства. - СПб : Коло, 2018. - С. 219-231.

4. Сиренко, Э.А. Преобразование планировочной структуры Москвы в первой половине XX века : диссертация ... кандидата архитектуры : 18.00.04. - М., 2000. - 205 с. : ил.

5. Аранович, Д.М. Планировка и архитектура социалистической Москвы // Новый мир. - 1934. - № 10. - С. 134-153.

6. Каганович, Л.М. 0 строительстве метрополитена и плане города Москвы : речь тов. Л. М. Кагановича на пленуме Моссовета с участием ударников Метростроя, фабрик и заводов Москвы 16 июля 1934 г. // Строительство Москвы. - 1934. - № 7. - С. 3-10.

7. Семёнов, В. Москву планировать и планово застраивать // Строительство Москвы. - 1932. - № 6. - С. 2-6.

8. Старостенко, Ю.Д. Основные положения Генерального плана реконструкции Москвы 1935 г. в свете материалов фонда Л.М. Кагановича (РГАСПИ) // Архитектурное наследство. - 2017. - Вып. 67. - С. 233-248.

\section{References}

1. Kaganovich L.M. 0 stroitel'stve metropolitena i plane goroda Moskvy: rech' tov, ll. M. Kaganovicha na plenume Mossoveta s uchastiem udarnikov Metrostroya, fabrik i zavodov
Moskvy 16 iyulya $1934 \mathrm{~g}$. [On the construction of the subway and the plan of Moscow city: speech comrade L. M. Kaganovich at the Plenum of the Moscow Sovet with the participation of strikers Metrostroi, factories and plants in Moscow July 16, 1934]. Moscow, Publ. gazeta "Udarnik Metrostroya", 1934. (In Russ.).

2. General'nyj plan rekonstruktsii goroda Moskvy. Postanovleniya i materialy [Master Plan for the reconstruction of the city of Moscow. Resolutions and Materials]. Moscow, Moskovskij rabochij, 1936. (In Russ.).

3. Starostenko Y.D. Kniga «General'nyj plan rekonstruktsii goroda Moskvy» 1936 goda: istoriya sozdaniya i ee rol' v formirovanii predstavlenij o rekonstruktsii Moskvy pervoj poloviny 1930-h godov [The Book "General plan for the Reconstruction of Moscow" (1936): the history of its creation and its role in the shaping ideas of Moscow reconstruction in the first half of the 1930s]. In Bondarenko I.A. (eds.) Arhitekturnoe nasledstvo. Vyp. 69 [Architectural heritage]. Saint Petersburg, Kolo, 2018, pp. 219-231. (In Russ.).

4. Sirenko E.A. Preobrazovanie planirovochnoj struktury Moskvy v pervoj polovine XX veka: dis.... kand. arh. [Transformation of Moscow planning structure in the first half of the 20th century. $\mathrm{Ph}$ d. (Architecture) diss.]. Moscow, 2000. (In Russ.).

5. Aranovich D.M. Planirovka i arhitektura sotsialisticheskoj Moskvy [Planning and architecture of socialist Moscow]. In Novyj mir [New world], 1934, no. 10, pp. 134-153. (In Russ.).

6. Kaganovich L.M. 0 stroitel'stve metropolitena i plane goroda Moskvy: rech' tov, ll. M. Kaganovicha na plenume Mossoveta s uchastiem udarnikov Metrostroya, fabrik i zavodov Moskvy 16 iyulya $1934 \mathrm{~g}$. [0n the construction of the subway and the plan of Moscow city: speech comrade L. M. Kaganovich at the Plenum of the Moscow Sovet with the participation of strikers Metrostroi, factories and plants in Moscow July 16, 1934]. Stroitel'stvo Moskvy [Construction of Moscow], 1934, no. 7, pp. 3-10. (In Russ.).

7. Semenov V. Moskvu planirovat' i planovo zastraivat' [Moscow plan and build up planned]. In Stroitel'stvo Moskvy [Construction of Moscow], 1932, no. 6, pp. 2-6. (In Russ.).

8. Starostenko, Y.D. Osnovnye polozheniya General'nogo plana rekonstruktsii Moskvy $1935 \mathrm{~g}$. v svete materialov fonda L.M. Kaganovicha (RGASPI) [The main features of the General Plan of Reconstruction of Moscow of 1935 on the basis of materials from the L.M. Kaganovich Fund (RGASPI)]. In Bondarenko I.A. (eds.) Arhitekturnoe nasledstvo [Architectural heritage], Vyp. 67, 2017, pp. 233-248. (In Russ.).

Старостенко Юлия Дмитриевна (Москва). Старший научный сотрудник Научно-исследовательского института теории и истории архитектуры и градостроительства (филиал ФГБУ «ЦНИИП Минстроя России») (111024, Москва, ул. Душинская, д. 9. нИИтИАГ. Эл.почта: ystarostenko@yandex.ru.

Starostenko Yulia Dmitrievna (Moscow). Senior Researcher at the Scientific Research Institute of Theory and History of Architecture and Urban Planning (branch of the Central Institute for Research and Design of the Ministry of Construction, Housing and Utilities of Russia) (111024, Moscow, Dushinskaya st., 9. NIITIAG). E-mail: ystarostenko@yandex.ru. 